\title{
CENTRIFUGAL AND CENTRIPETAL FORCES DRIVING RUSSIAN LANGUAGE NORMS*
}

\author{
Arto Mustajoki \\ University of Helsinki, \\ Helsinki, Finland \\ HSE University, \\ Moscow, Russia
}

Ekaterina Protassova

University of Helsinki, Helsinki, Finland

Maria Yelenevskaya

Technion-Israel Institute of Technology, Haifa, Israel

Russian, as a pluricentric language, demonstrates differences in pronunciation, lexis, syntactical structures, and regional specificity of grammar deviations. The imposition of a norm, which is difficult even in the metropolis, is hardly possible in the diaspora, where host countries' realities have a strong impact on the Russian language spoken outside of Russian borders. Even support of the Russian language turns into a double-edged sword, as Russian institutions offering it to the diasporic communities refuse to admit the growing pluricentricity of the Russian language. Although almost 30 years have passed since the dissolution of the Soviet Union, Russian heritage remains strong in the post-Soviet space, and many countries continue using Russian in public settings and in education. Regional varieties of Russian increasingly drift away from the "Moscow norm", although it still dominates culturally. New European borders and economic conditions stipulate new regulations in the use of traditional international languages. The debate on the norm and the struggle for bi- and multilingualism characterize the current situation with the Russian language in the world. At the same time, it is important to point out that due to diasporans' transnational ties, globalization of Russian electronic media, and growing commodification

* Citation: Mustajoki, A., Protassova, E., Yelenevskaya, M. (2021). Centrifugal and Centripetal Forces Driving Russian Language Norms. In Quaestio Rossica. Vol. 9, № 2. P. 715-732. DOI 10.15826/qr.2021.2.605.

Цитирование: Mustajoki A., Protassova E., Yelenevskaya M. Centrifugal and Centripetal Forces Driving Russian Language Norms // Quaestio Rossica. Vol. 9. 2021. № 2. P. 715-732. DOI 10.15826/qr.2021.2.605. 
of Russian, it is often used as a lingua franca on the territory of the former Soviet Union and in immigrants' host countries. This requires a high degree of stability of the main linguistic features to ensure mutual understanding in communication. Russian speakers stick to their language and elevate its status whenever they feel mistreated or underrepresented in their countries of residence, or when they see economic benefits in its use.

Keywords: Russian language studies, bilingualism, linguistic variation, diaspora, language policy, the official norm

Русский язык как плюрицентрический демонстрирует различия в произношении, лексике, синтаксических структурах и региональную специфику грамматических отклонений. Навязать норму сложно даже в метрополии и вряд ли возможно в диаспоре, где реалии принимающих стран оказывают сильное влияние на тот язык, на котором говорят за пределами российских границ. Даже поддержка русского языка превращается в обоюдоострый меч, так как российские институты, предлагающие его диаспорным общинам, пока отказываются признать его растущую плюрицентричность. Хотя с момента распада Советского Союза прошло почти 30 лет, российское наследие остается сильным на постсоветском пространстве, и многие страны продолжают использовать русский язык в общественном пространстве и в образовании. Региональные разновидности русского все больше отходят от «московской нормы», хотя и по-прежнему доминируют в культурном отношении. Новые европейские границы и экономические условия предусматривают появление новых правил использования традиционных международных языков. Дебаты о норме и борьбе за дву- и многоязычие характеризуют нынешнюю ситуацию с русским языком в мире. В то же время важно отметить, что из-за транснациональных связей диаспор, глобализации российских электронных СМИ и растущей коммерциализации русского языка он часто используется в качестве лингва франка на территории бывшего Советского Союза и в странах проживания иммигрантов. Чтобы обеспечить взаимопонимание в коммуникации, требуется высокая степень устойчивости основных языковых особенностей. Русскоговорящие поддерживают свой язык и борются за сохранение его статуса всякий раз, когда чувствуют недостаток уважения или пренебрежение к нему в странах своего проживания или же когда видят экономическую выгоду в его использовании.

Ключевые слова: изучение русского языка, двуязычие, языковая вариация, диаспора, языковая политика, официальная норма

No language ever remains static, and changes become particularly dramatic during periods of political upheaval, social unrest, and massive migration. The Russian language is no exception. It was proven in the wake of the October Revolution of 1917 [see: Comrie, Stone, Polinsky], and has again been witnessed in the post-Soviet period. A drop in the number of native speakers and foreign language learners but growing numbers 
of heritage speakers, some liberalization of the norm and evolvement of new regional varieties, massive borrowings from English, and the emergence of new contact pairs - these are just a few of the phenomena marking the current situation with Russian. The status and functioning of the Russian language in and outside the nation have become an important issue of state politics and a subject of heated public debate in the metropolis and in the diaspora. Despite public interest in the topic, the effect of drastic changes in the sociolinguistic situation of Russian on learner goals and strategies remains under-researched. So are the dilemmas experienced by teachers who face increasingly diverse student populations and curriculum requirements. Moreover, they have to decide how to combine well-tested but conservative approaches to language learning relying on classic literature with innovative pedagogies requiring that students be immersed in the live language, that very language which the linguist Maxim Krongauz aptly characterized as "the Russian language on the verge of a nervous breakdown” [Кронгауз].

The main purpose of this essay is to analyze how language policies and the sociolinguistic situation of the Russian language in different countries influence Russian studies. Having these problems in mind, we pose several research questions:

- Do centripetal or centrifugal tendencies prevail in the current development of the Russian language and how is it reflected in Russian studies?

- Who learns Russian today and for what purpose?

- What is the impact of economic globalization on the professional practices of Russian-language teachers?

- How does Russian-language teaching outside the nation reflect complex relations between the metropolis and diasporas?

Material for analysis was drawn from different types of sources: electronic media and Internet discussion forums devoted to the functioning of the Russian language, websites bringing together Russian-language teachers and parents coordinating activities that facilitate language maintenance among second-generation diasporans. Our attention to electronic media and discussion forums is not accidental. Language teaching to a large extent depends on the dominant language ideologies and language policies of the host country. Today, in their relations with educational institutions, parents and students feel they are customers who have the right to receive an adequate and appropriate service, as they understand it. Educational institutions cannot disregard this trend in the public consciousness and often adjust their teaching goals and strategies to their "customers" wishes and needs. And an understanding of these needs is often shaped by the media today. That is why we consider it vitally important to study not only scholarly literature, but also media texts to see how lay people's opinions about language learning are shaped, becoming language ideologies.

When analyzing the collected data, we applied thematic analysis, metaanalysis, sociolinguistic methods and participant observation as the most fitting approaches to qualitative data. First, we explain the terminology 
used. We will reflect upon current debates surrounding Russian as a world language, its norms, pluricentricity and ideas about teaching it at home and abroad as controversial multidirectional forces. Then, to illustrate these conceptions, we will explore several cases of the adaptation of Russian language teaching to the local context in five countries. We will conclude with a discussion about the necessity of changing the methods of Russian language instruction.

\section{Centripetal and centrifugal forces of the language revisited}

It was Mikhail Bakhtin who introduced these physical terms to the study of literature and language [Бахтин]. In his view, the category of a unitary language is a theoretical expression of the historic processes of language unification and centralization. It is the manifestation of the centripetal forces of the language. At the same time the unitary language is layered and includes sociolects, professional jargons, idiolects of people in authority, sociolects of different generations, fleeting fashions, and others. At every moment of its existence the unitary language is confronted with heteroglossia and has to resist centrifugal forces in order to secure maximal mutual understanding by language users. Bakhtin emphasizes that the layered structure of a language and its heteroglossia are indicators of both the statics and dynamics of the language, and they get wider and deeper while the language is alive and developing. The centripetal forces always act together with the centrifugal ones. Thus, verbal and ideological centralization and unification are inseparable from decentralization and disassociation processes.

Bakhtin's ideas of centripetal and centrifugal forces in language development were appreciated in pedagogical theory. K. S. and Y. M. Goodman theorize that if language were static and unchanging, it would inhibit its users in learning and communicating their responses to new experiences [Goodman K. S., Goodman Y. M.]. In interacting with others, learners are exposed to the conventions of the social language. When language changes, there is always balance between the creative force and the need to communicate. The inventor in the learner uses the acquired reservoir of social forms and uses these resources to create new inventions. From this standpoint individual language development can also be viewed as driven and shaped by the interplay of centripetal and centrifugal forces.

We believe that many sociolinguistic processes can be explicated in terms of the theory of interaction of centripetal and centrifugal forces. For example, they are at work in polycentric languages. On the one hand, different conditions of living, customs and habits lead to divergence in language development (centrifugal forces). At the same time, cultures behind pluricentric languages retain common features and they are easily recognized by people speaking different varieties of the same language. Moreover, after these varieties stabilize, a certain convergence can occur, driven by centripetal forces. A case in point is English in the era of globalization.

Studies of language norms and deviations can also be viewed in terms of the theory of centripetal and centrifugal forces. There is tension between 
social actors who support strict adherence to the norm and find it binding in communication. There are also those who point out that different contexts and different social characteristics of speakers will inevitably lead to variations [Карасик, Дмитриева; Крысин, 2011; Региональные варианты национального языка]. If these variations are accepted by a large number of speakers, they become normalized. Moreover, writers and poets, those very people whose use of the language serves as a model for others are also language innovators. Their creative use of the language is driven by centrifugal forces which may disrupt the norm.

A. Mustajoki writes that democracy and a strict official norm may be interrelated [Мустайоки, 2013; Mustajoki, 2016]. N. Coupland and T. Kristiansen proposed two opposite interpretations: when the norm is imposed from 'above', it is made clear that only a small group of people decides how others should speak and write [Coupland, Kristiansen]. From a different perspective, standardisation allows people to communicate freely in a comprehensive way and to understand each other. Schooling reveals that a high proficiency in a mother tongue is reached though thousands of hours of language use. In a heritage language case, it might be considerably harder to attain the same level. The non-standard spoken variant is the language a child acquires naturally, and normalisation achieved through literacy requires learning rules of the standard language. Moreover, teaching Russian as a foreign language and teaching it as a heritage language can be especially challenging because of the same discrepancy [Мустайоки, 2019].

\section{Russian in the world}

Russian speakers can be found in almost every country of the world. Founded in 1721, the Russian Empire continued to expand throughout the eighteenth and the first half of the nineteenth century. It reinforced its power through the Orthodox religion and the Russian language. Emigration from Russia began with Old Believers in the 1660s. It continued with its Jewish population escaping pogroms in the early twentieth century and was followed by the "White" emigration in the wake of October Revolution of 1917. After that, both large waves and smaller trickles of Russian-speaking émigrés from the USSR disseminated their language and culture wherever they settled. In fact, some speech communities developed their own norms of oral and written speech differing from those imposed by the Soviet school system, while others continued using the old pre-revolutionary orthography and lexis [cf.: Зеленин; Плетнева]. The Moscow norm ${ }^{1}$, connected to the official ideology, not only dominated language use in the Russian Federation

\footnotetext{
${ }^{1}$ The literary norm of the Russian language began to form in the middle of the eighteenth century. It evolved on the basis of writings by M. Lomonosov, N. Karamzin and A. Pushkin. Like other domains of Russian cultural life, it fluctuated between Moscow and St Petersburg standards. Ultimately, the Moscow version won, and in pronunciation it is modeled after the speech of the actors of Moscow theaters. The concept of a literary norm, the classification of its elements and permissible variations are a controversial issue in Russian linguistics [see, e. g.: Крысин, 2012; Загоровская] and are frequently discussed in the media.
} 
(RF) but also in the other 14 republics of the Soviet Union, while the local lexis was viewed as exoticisms and barbarisms. After the dissolution of the Soviet Union, Russia's neighboring countries, which had different histories of Russian language use, chose different policies towards the Russian language and its speakers. Inevitably, they had to deal with the legacy of the Soviet period, including Moscow's insistence on strict adherence to the metropolitan norm of the Russian language. However, globalization works in such a way that the former centers of norm-prescription cannot impose the dominant variety on the periphery in the same manner as before. The superdiversity of schools in Russia ${ }^{2}$ also makes it difficult to continue requiring that students should use highly standardized language deemed to be the only "correct" variety. Available statistics fail to indicate precisely how many people speak and write normative Russian. The numbers are unlikely to exceed two or three percent, and according to the results of the Unified State Examination ${ }^{3}$, they did not exceed $4 \%$ in 2019. Russian is becoming a heritage or foreign language for an increasing number of families in which it used to be the mother tongue, although these families continue speaking it on a daily basis [Isurin; The Russian Language Outside the Nation; Muth; Post-Soviet Migration and Diasporas].

Russian, once mentioned by Michael Clyne as belonging to the pluricentric scope, has existed in different varieties formed on the territory of Russia thanks to contacts with indigenous and migrant languages. It is present in the countries which emerged after the collapse of the USSR, in neighboring territories (e. g., Alaska, China, and Finland), in ex-socialist countries where it was a compulsory school subject, and in places of old and new emigration (from Old Believers in South America to IT-professionals in Silicon Valley). Russian has formed regio- and ethnolects that continue to re-mix during new demographic processes. United by the culture expressed in the language, Russian speakers have diverse backgrounds, and belong to different ethnicities and confessions. Their political views differ, yet they tend to share cultural values and rituals, such as festive traditions, as manifested in celebrating the New Year and Victory Day, and the intergenerational transfer of educational practices when children are made to learn specific poems by heart and sing specific songs; otherwise, their language adopts to the new way of life.

Today, ideas of pluricentricity within the Russian language are gaining momentum [see: Плюрицентрические языки; Kamusella; Katona; Larina, Mustajoki, Protassova; Russian Language in the Multilingual World; The Soft Power of the Russian Language; Yelenevskaya, Protassova]. In terms of pluricentricity, Russian is an interesting case. It still meets only some of the criteria named by M. Clyne [Clyne] and further developed by

\footnotetext{
${ }^{2}$ The Russian Federation includes autonomous republics and regions whose school curricula may differ from those in the center; in addition, there are private schools with their own rules.

${ }^{3}$ Unified State Examination is a series of matriculation exams taken by high-school students in order to apply for university studies.
} 
R. Muhr [Muhr, p. 29-31], but its pluricentricity which received a powerful momentum with the dissolution of the Soviet Union and subsequent mass migration is developing quickly. Today, the language demonstrates different stages of pluricentricity in different countries (cf. Belarus, where it has an official status, Kazakhstan and Kirgizia, where it has the status of interethnic communication; Estonia, Latvia and Lithuania, where it is not even recognized as a minority language but is waiting for recognition; Israel where it does not have any formal status but is widely used in public life. Whatever the status of Russian in these and other countries with large Russian-speaking communities, the local versions are closely connected to the culture of those communities and become part of their self-identification. Most speakers of the dominant variety, however, are either unaware that their language is developing in the direction of pluricentricity or reject it. So far, few steps have been made towards the recognition of Russian varieties as world Russian languages. These varieties have not been codified yet, and this impedes determining their norms and official acknowledgment of their standard forms. The centrifugal forces driving Russian away from orbiting Moscow alone, and the concurrent centripetal forces acting on the language outside Russia's borders, continue to support the idea of a large and rich cultural and linguistic common space. Old ties persist, and the states which used to be part of the Soviet Union or its allies share memories, and traditions, and understand each other better than people from other countries. Although diversity requires good will and continued efforts to maintain these ties, not all nations are up to this challenge and some people, including functionaries, would rather stick to the old ways, preserving the language policies and models of use as they were in the Soviet period. A vision of freedom pulls speakers of Russian apart, while their wish to communicate with each other brings them together.

\section{The current debate on the Russian norm}

The concept of one and only one "great and mighty Russian" ${ }^{4}$ had been firmly established by the middle of the twentieth century and was based on the Moscow dialect that remained alien even to the former capital St Petersburg (Leningrad), not to mention multiple regions where "standard" Russian was in contact with local varieties and 160 indigenous languages. What is correct and acceptable and what is not is a sensitive issue. These questions seldom leave educators and lay people indifferent, sparking arguments and often ending in animosities. Therefore, these clashes have been within linguists' purview for the last two decades.

The Russian president Vladimir Putin is personally involved in shaping language policy and often expresses his opinion about the quality of Russian as

\footnotetext{
${ }^{4}$ This phrase, which has since become a speech cliché, was coined by the Russian writer of the nineteenth century, Ivan Sergeevich Turgenev who claimed Russian to be "truthful and free". He also wrote (in 1882): "Were it not for you - how is one not to fall into despair at the sight of all that is happening in our house?..." (translated by Alex Cigale).
} 
it is spoken today. He takes active part in the work of the Presidential Council on the Russian language, established in 2014. Its goal is to advise, coordinate and "improve the state policy on developing, protecting and supporting the Russian language, guaranteeing citizens of the RF the right to use the official language". At a meeting of the council, which took place on 5 November 2019, Putin set them the target of preparing a unified complex of dictionaries, reference- and grammar-books for guiding readers on the normative use of the language. These norms, according to the president, must be compulsory for all the state institutions, including legislative, executive and judicial bodies, as well as educational institutions and the mass media.

In Putin's view, the goal of amendments to laws concerning the official language and the languages of the peoples of Russia is to endorse the Moscow norm, making Russian vivid and expressive, and guarantees that it remains among the best-shaped languages, beautiful, and connotationally and figuratively rich. Putin also suggested replacing Wikipedia with a Russiabased electronic encyclopedia. The Presidential Council emphasized that some countries had "waged a war against the Russian language", which should be perceived as proof that the Russian language is "a most powerful and formidable weapon, and as such has to be at full combat alert". At the same time the President talked about the "soft power" of the language which can be fully applied only if the Russian economy flourishes, and the well-being of Russian citizens grows, in its turn triggering the growth of interest in the Russian language [Колесников]. Clearly, the maintenance and support of the normative Russian language has become an essential part of state politics [cf.: Ноянзина, Омельченко, Суртаева].

The speaker of the Moscow City Duma, Alexei Shaposhnikov, suggested introducing a proficiency examination testing knowledge of the Russian language norm for job applicants in the public sector. Notably, the use of obscenities is among the most frequent violations of the norm in mass media, and perpetrators face penalties. In 2019, a fine was imposed more than 400 times. Today, the law is applicable only to language use in the public sphere, while in the private sphere, e. g., in informal Internet communication, it is not binding. Strictness of the new language laws has motivated journalists to regularly attend seminars dedicated to the norms of Russian [Рожкова].

Debates about language norms are currently among the most heated. Ksenia Turkova, a journalist from "Voice of America", compared hatred towards certain words and expressions among Russian and English speakers. She came to the conclusion that Russians hate the form, whereas Americans hate the content, i. e., insulting, humiliating or xenophobic meanings [Туркова]. At the same time, researchers have introduced a new aspect to studies of the norm, looking at it from the perspective of everyday oral communication [е. g.: Безяева; Северская]. Massive amounts of data already collected serves to determine the limits of the current conversational norm and the antecedents of its deviations.

This view finds confirmation in the interview by the Harvard Business Review Rossija [Натитник] with Dr. Boris Iomdin, a Russian linguist 
affiliated with the Vinogradov Russian Language Institute of the Russian Academy of Sciences. Iomdin investigates how the norm differs in various generations of Russian speakers and analyzes factors influencing the use of lexis and morphology. His work considers culturally split worlds in which Russian speakers are divided by age, social class and region. He illustrates his views with examples of Russian speakers' intolerance of varieties which are not their own. In fact, some Internet users made it their hobby to compile lists of words that serve as markers of "low" culture. This language policing even triggered the emergence of the term "grammar Nazis". Some of the examples Iomdin cites reveal paradoxes in lay people's perception of changes in the language. Thus, some of the words with diminutive and endearing suffixes reminding one of baby talk are considered to be vulgar by intellectuals and are becoming taboo.

Another example of this emotional attitude to the Russian language and lay people's involvement in the language norm debate is a scandal that shook the Russian-language virtual world, before spilling over into the real world. The trigger was a Facebook post by Gasan Guseinov, a well-known linguist and professor at a prestigious Moscow university, Higher School of Economics. A keen observer of language changes [see, e. g.: Гусейнов, 2003; Гусейнов, 20126], he wrote that in Moscow it had become next to impossible to find printed materials in Russian other than those written in foul language appropriate for a cesspool ${ }^{5}$. He also acknowledged the hundreds and thousands of Ukrainians, Tatars, Kyrgyz, Uzbeks, Chinese and Germans in the city. Guseinov, thus, did not mean that the Russian language itself had deteriorated, but that the way people speak and write it is deplorable. The post divided Facebook users: numerous angry comments accused Guseinov of Russophobia and demanded a public apology; his supporters, on the other hand, claimed that he was a true patriot fighting for a better country through language. The ethic committee of his university recommended that Guseinov should apologize, but he refused, telling journalists that his post was against the hate language permeating mass media.

Several years earlier, speaking at a conference in Delhi, Guseinov said that in the Soviet period, Russian had been a "regional global language" (studied in the socialist countries and those still planning to build socialism); in addition, it was formally recognized by the United Nations Security Council as a working language. Guseinov speculated about twin spheres of a global language. The outer application can be quantified (estimating domains in which it is used: industry, science, education, translation, management, politics, defense, etc.); the inner application (the logic and philosophy of the language, the way it is used in cybernetics, education, management, etc.) can be described and evaluated, but not quantified. The

${ }^{5}$ The authors admit that this translation is rather awkward and even puzzling. We were not the only ones grappling with the problem of rendering the precise meaning of the words. An American journalist working in Moscow published a tongue-in-cheek article "Is your language sordid and gross?" revealing the difficulty of adequately translating the words used in the original [Berdy]. 
representation of this second sphere can be found in the classic literature of the nineteenth - first half of the twentieth century, in works by Pushkin, Dostoevsky, Tolstoy, Chekhov, Gorky, Mayakovski, Tsvetaeva, Mandelstam, Pasternak, and others, and also in the philosophical and political writings by Lenin, Trotsky, and Stalin. It was the language that rendered their ideas and helped to introduce them to global audiences, even allowing them to become dominant in some parts of the world. The lists were different for those in the Soviet Union and for foreigners [Гусейнов, 2012a]. Today, they still differ for those who live in Russia and abroad. The symbolic power of a language may be great irrespective of the total number of its speakers.

In the common culture of Russian speakers one can see how the legacy of an imperial and Soviet past intermingle with the influence of internet culture, as illustrated by such state-sponsored international events as the Total Dictation and the Pedagogical Forum of the Russian World. The Total Dictation, started up as a local initiative of the Novosibirsk State University and has been conducted since 2004. Gradually it evolved into a worldwide event, and in 2019 more than 200,000 people residing in 81 countries participated. The event's goal is to popularize Russian literacy, and the main criterion of assessment is strict adherence to grammar rules, with no deviations allowed. The organizers encourage the spirit of competition among participants, and several government-sponsored projects were launched to develop online teaching materials that can be used for cramming before the contest. A team of well-established and experienced professionals set it as their goal to make various orthographical and punctuational pitfalls of the Russian language well understood and practiced. The idea is excellent, but what is missing in the event is free use of the language for expression. Moreover, the norm imposed does not take into account the fact that language keeps evolving and that in real use it is multifaceted and multi-registered and has social and geographic varieties. In some sense, the ideology behind the Total Dictation seeks triumph of the centripetal forces, thus causing some participants residing far from the center to suffer disappointment when forms acceptable in their reginal varieties are rejected. Foreign researchers are sometimes repelled by the name of the event, but they fail to notice the irony noticeable to some Russian speakers: "Total" is reminiscent of totalitarianism and "dictation" suggests a lack of choice. Put together, these connotations hardly seem humorous.

The Pedagogical Forum has been held since 2014 under the auspices of the Russian World Foundation ${ }^{6}$, the Russian Academy of Education and Association of the Teachers of the Russian Language and Russian Literature, MAPRYAL. The forum brings together academic linguists, teachers of Russian as a L-1, L-2, heritage and foreign language, and publishers. In 2019 more than 400 participants from 52 countries took part. Among

${ }^{6}$ The Russkii Mir foundation was set up in 2007 to consolidate the diaspora and reinforce its ties with Russia. It seeks to promote Russian studies abroad and, in this way, to promote the country's image. 
the main goals of this annual event is the development of a unified educational space enabling instructors to share their experiences and teaching materials, present educational projects and work out new formats of language teaching, which incorporate the latest technological innovations. This meeting allows teachers in various schools in Russia and post-Soviet space, as well as émigrés who have opened private Russian kindergartens and schools in their host countries, to be kept abreast of cutting-edge language teaching methodologies and the latest research in Russian linguistics. Educators can participate in a contest between innovative projects, and the winners can count on financial support from the Russian World Foundation. The most important thing for teachers living outside Russia, as well as those coming from small provincial towns of Russia, is to network with their colleagues. Some of these contacts bear fruit and result in webinars, an exchange of master classes and teaching materials. The main themes of the Pedagogical Forum, such as "Language norm, its types and problems", "The text of culture and the culture of text", and "Russian language and culture: Interconnections and interactions" reflect the elite's perception of Russian language pedagogy as a vehicle for disseminating Russian culture and values.

In 2012, the Russian government issued a document formulating a strategy for national policy [О стратегии государственной национальной политики]. It presupposes that the state supports and protects the cultures and languages of the peoples of the Russian Federation. The Russian Ministry of Education is currently implementing a program for the support for Russian and minority languages of the Peoples of Russia [Об утверждении ведомственной целевой программы]. It aims to promote language norms and provide conditions for a fully-fledged functioning and development of the Russian language as the basis for Russian citizens' self-identification. The program stipulates that the number of events dedicated to the dissemination and reinforcement of the Russian language outside Russia should grow, and that Russian science, culture and education should be popularized worldwide. The Federal Agency for Ethnic Affairs was formed to monitor and regulate the multilingual and multiethnic situation in Russia and its population of 193 ethnicities. The Russian language is viewed as a major factor in the supra-ethnic consolidation of society. Russia proclaimed 2020 the "Year of folk art" in the RF as a measure to popularize cultural diversity of the country. Still, because of previous tsarist attempts at Russification, which only intensified in the Soviet period, many indigenous languages face extinction. Despite the efforts of linguists and local enthusiasts, properly documenting and preserving these languages is a complicated task, requiring expertise and long-term funding. Many websites have been launched and are frequented by members of the various ethnicities populating Russia. Their subscribers wish to correct historical injustices and campaign for more consistent and wellplanned support of endangered languages and cultures, including creating better opportunities for the use of these languages in the public sphere. Meanwhile, the Russian language is the subject of an amendment in the new Constitution [Емельяненко]: its role of state-building should be assured. 
Current language policies in Russia are contradictory and follow the general trajectory of those seen throughout the history of Russian society: battles between Slavophils and Westerners are still ongoing [Mustajoki, Protassova; Larina, Mustajoki, Protassova]. In terms of language development, the most feared phenomenon for contemporary Slavophils is the massive amount of borrowing from English that is allegedly undermining Russian culture and values [Колесов; Савельева]. Debates over what is best for Russia remain acrimonious, and the adoration of the imagined continues, with a belief in non-existent unchanging norm as strong as ever among the conservatives. Yet, as mentioned earlier, linguistic research reveals that deviations have always existed [Крысин, 2007] and the actual use of language hardly ever follows prescriptions. When communication is deficient, misunderstandings arise leading to conflicts. Language varieties spoken in different regions of Russia and abroad neither diverge significantly nor are they completely separated from the dominant variety of the center, pointing to the coexistence of centripetal and centrifugal forces. Yet, fights about and for the Russian language and its norms persist.

\section{Discussion and conclusion}

Language and culture are forces that can divide or unite. They influence identities, careers, families, children's upbringing, sport, and leisure time. In its symbolic function, language is a powerful instrument of unification. Unfortunately, sometimes it serves as a vehicle of xenophobia, undermining complex constellations of feelings, and as an instrument of manipulation by nationalists and political extremists.

A pluricentric language can belong to any sociolinguistic category. As the state language, its acquisition should be ensured governmentally through legal measures. For some countries, it is a language of neighbors - friends or foes. On a global level, it can play the role of a language of science, culture, prestigious education, career opportunities, and commercial usefulness. For some, it can be the language of religion and shared values. In the diaspora, Russian turns from a world language into a minority language studied mostly in private and in state-run institutions, but primarily for use in limited contexts. Sometimes courses are available for anyone wishing to acquire the language, sometimes only for those who are ethnically linked with it. In many cases, only low-level courses are offered, which prevents learners from attaining advanced levels of proficiency. The status of Russian as a foreign language dropped from that of an essential ideological tool of the Soviet republics and countries of Eastern Europe to the language of a country with a contentious reputation. Diasporic communities have a dilemma: should they initiate teaching themselves? If they do, at whose expense, and to what extent? Should opportunities for learning be available only for children or also for adults? Should learning goals be limited to oral communication or include the written word? Should students study literature and culture in Russian or in the language of their immediate environment? Confronted with these questions, teaching methodologists 
are investigating how to modernize the field of Russian studies by incorporating state-of-the-art techniques and training teachers to face these challenges head on.

The language of diaspora speakers is often fossilized. The great Russian émigré writer Vladimir Nabokov compared his own Russian to "frozen strawberries". Not many people are sensitive enough to notice and realize that the language is an ever changing and spontaneously developing organism. So, noting differences between how people use Russian in the metropolis and their own speech habits, some people are convinced that the language of the metropolis has deteriorated since they left. In fact, the language always reflects the "we-code" of its users; in the case of diasporas, it is a reflection of the peculiarities of life of the immigrant group using it.

Differences in language use have always divided social classes. There have been many an Eliza Doolittle in Russian history, with their vernacular speech viewed as an aberration among polite society. Imperial attempts to preserve strong centralized power were implemented by imposing a language norm. A project that might seem unrealistic in the context of such a huge territory nevertheless succeeded in making the Moscow norm a prestigious variety. In the post-Soviet period, language changes accelerated greatly, making it difficult to capture all the innovations in dictionaries and textbooks, which often leads to conflicting attitudes to them today. Snobbishness and coercion on the part of elites can hardly improve the speech of the less educated people.

There is hardly such a thing as "correct" and "incorrect" language. Rather than imposing a norm, educators should show young people how society evaluates people on the basis of their speech, and how criteria for assessment evolve and change over time. It is important to teach young people both in the metropolis and in the diaspora to distinguish between registers and when to adopt them, depending on the context.

The linguistic hybridity and fluctuation of the norm is already a new reality for different languages, situations, and theoretical conceptions [Ritzau, Madsen]. The diversified life of Russian speakers is sometimes viewed through the lens of purism as shameless and alien, and their language as defective. In fact, it is multifaceted and offers evidence of a whole spectrum of modern ways of self-expression. These two perspectives entail a juxtaposition of the individual and collective views from within a sociolinguistic case and from outside, which we have tried to demonstrate here. Teachers and parents do their everyday work in the best way they can, and methodologists of various levels summarize their experience, whereas the ideological centers in Moscow and St Petersburg try to proclaim the dominance of the "correct" norm in Russian over the multilingual aspects of life. Linguistic and cultural repertoires must not be restricted to one theoretical language but enriched through creative hybridization, combining centrifugal and centripetal tendencies. In our further research projects, we are going to explore approaches to teaching pluricentric languages, the involvement of old and new regions of Russian 
use in pedagogical work and the interaction between them, and the role of the commodification of Russian abroad in the life of diasporans.

\section{Список литературы}

Бахтин М. М. Слово в романе. М. : Пальмира, 2017. 229 с.

Безяева М. Г. Коммуникативное поле нормы в звучащем тексте // Русский язык за рубежом. 2017. № 2. С. 24-30.

Гусейнов Г. Ч. Д. С. П. Советские идеологемы в русском дискурсе 1990-х. М. : Три квадрата, 2003. 272 с.

Гусейнов Г. Ч. Новая роль русского языка в мире как предмет изучения и преподавания // Гефтер : [сайт]. 10.05.2012a. URL: http://gefter.ru/archive/4359 (дата обращения: 04.06.2020).

Гусейнов Г. Ч. Нулевые на кончике языка: краткий путеводитель по русскому дискурсу. М. : Изд. дом «Дело» РАНХиГС, 20126. 240 с.

Емельяненко В. Если не русский язык - как нам родниться? // Рос. газ. : [сайт]. 2020. №. 48. 04 марта. URL: https://rg.ru/2020/03/04/pochemu-v-konstitucii-neobhodimapopravka-o-russkom-iazyke.html (дата обращения: 04.06.2020)

Загоровская O. В. Нормы русского литературного языка: типология и основания для классификации // Изв. Воронеж. гос. пед. ун-та. Сер.: Педагогические науки. 2016. № 3. С. 121-126.

Зеленин А. Язык русской эмигрантской прессы (1919-1939). Tampere : Univ. of Tampere, 2007. 663 c.

Карасик В. И., Дмитриева О. А. Лингво-культурный типаж: к определению понятия // Аксиологическая лингвистика: лингвокультурные типажи / под ред. В. И. Карасика. Волгоград : Парадигма, 2005. С. 5-25.

Колесников А. Законно русские // Коммерсантъ : [сайт]. 2019. № 203. 06 нояб. URL: https://kommersant.ru/doc/4149158 (дата обращения: 04.06.2020).

Колесов В. В. Русская речь: вчера, сегодня, завтра. СПб. : Юна, 1998. 248 с.

Кронгауз M. Русский язык на грани нервного срыва. М. : Знак : Языки славян. культур, 2008. 232 с.

Крысин Л. П. Русская литературная норма и современная речевая практика // Русский язык в научном освещении. 2007. № 2. С. 5-17.

Крысин Л. П. Вариативность нормы как естественное свойство литературного языка // Изв. РАН. Серия литературы и языка. Т. 70. 2011. № 4. С. 3-8.

Крысин Л. П. Культура речи и функциональная социолингвистика // Вопросы культуры речи : сб. ст. М. : Ин-т рус. яз. им. В. В. Виноградова РАН, 2012. С. 38-44.

Мустайоки A. Разновидности русского языка: анализ и классификация // Вопр. языкознания. 2013. № 5. С. 3-17.

Мустайоки A. Что такое «владение языком» и каковы истоки современной методики преподавания русского языка как иностранного // Но мы сохраним тебя, русский язык! / отв. ред. В. И. Карасик. М. : Флинта, 2019. С. 353-361.

Натитник A. «Если люди говорят не как мы, нам кажется, что они плохие» // Harvard Business Review - Россия : [сайт]. 2019. 24 дек. URL: https:/hbr-russia.ru/ biznes-i-obshchestvo/fenomeny/817433 (дата обращения: 04.06.2020).

Ноянзина О. Е., Омельченко В. А., Суртаева О. В. Приоритеты государственной политики Российской Федерации в области сфер использования русского языка // Society and Security Insights. T. 1. 2018. №. 4. C. 125-140. DOI 10.14258/ssi(2018)4-09.

О Стратегии государственной национальной политики Российской Федерации на период до 2025 года : указ Президента РФ от 19 декабря 2012 г. № 1666 // Гарант.Ру : информ.-прав. портал. URL: https://www.garant.ru/products/ipo/prime/doc/70184810 (дата обращения: 04.06.2020).

Об утверждении ведомственной целевой программы «Научно-методическое, методическое и кадровое обеспечение обучения русскому языку и языкам народов Российской Федерации» : распоряжение Минпросвещения России от 16.05.2019 
№ P-60 // КонсультантПлюс : [сайт]. URL: http://www.consultant.ru/document/cons doc_LAW_356191 (дата обращения: 04.06.2020).

Плетнева А. А. Народное правописание и реформа орфографии 1917-1918 годов // Тр. Ин-та рус. яз. им. В. В. Виноградова. Т. 13. 2017. С. 466-473.

Плюрицентрические языки / под ред. Д. Д. Шайбаковой, А. Д. Маймаковой, С. А. Мейрамовой. Алматы : Ұлағат, 2016. 244 с.

Региональные варианты национального языка / под ред. А. П. Майорова. УланУдэ : Изд-во Бурят. ун-та, 2013. 295 с.

Рожкова E. Единый журналистский экзамен // Коммерсантъ : [сайт]. 2019. 23 нояб. URL: https://www.kommersant.ru/doc/4170171 (дата обращения: 04.06.2020).

Савельева Л. В. Русское слово: конец ХХ века. СПб. : Логос, 2000. 213 с.

Северская О. И. Орфографические нормы сквозь призму паронимии и сходнозвучия // Языковая норма : Виды и проблемы / под ред. Л. А. Вербицкой. СПб. : РГПУ им. А. И. Герцена, 2018. С. 191-200.

Туркова К. Какие слова бесят русских и американцев? // Голос Америки. 2019. 27 нояб. // Facebook : [website]. URL: https://www.facebook.com/wat$\mathrm{ch} / ? \mathrm{v}=445762846124011$ (дата обращения: 30.04.2021).

Berdy M. A. Is Your Language Sordid and Gross? // Moscow Times : [website]. 2019.

15 Nov. URL: https://themoscowtimes.com/2019/11/15/is-your-language-sordid-andgross-a68197 (accessed: 04.06.2020).

Clyne M. Pluricentric Languages. Different Norms in Different Countries. Berlin : Mouton de Gruyter, 1992. 481 p.

Comrie B., Stone G., Polinsky M. The Russian Language in the Twentieth Century. Oxford : Clarendon Press, 1996. XI, 385 p.

Coupland N., Kristiansen T. SLICE: Critical Perspectives on Language (De)Standardisation // Standard Languages and Language Standards in Changing Europe / ed. by T. Kristiansen, N. Coupland. Oslo : Novus, 2011. P. 11-35.

Goodman K. S., Goodman Y. M. Making Sense of Learners, Making Sense of Written Language. N. Y. : Routledge, 2014. 288 p.

Isurin L. Russian Diaspora: Culture, Identity, and Language Change. Gottingen : Walter de Gruyter, 2011. 249 p.

Kamusella T. Russian: A Monocentric or Pluricentric Language? // Colloquia Humanistica. 2018. № 7. P. 153-196. DOI 10.11649/ch.2018.010.

Katona É. Russian Pluricentricity in Development: Russian in Estonia as an Example // European Pluricentric Languages in Contact and Conflict / ed. by R. Muhr, J. A. Mas Castells, J. Rueter. Berlin : Lang, 2019. P. 11-25.

Larina T., Mustajoki A., Protassova E. Dimensions of Russian Culture and Mind // Philosophical and Cultural Interpretations of Russian Modernisation / ed. by A. Mustajoki, K. Lehtisaari. N. Y. : Routledge, 2017. P. 7-19.

Muhr R. Linguistic Dominance and Non-Dominance in Pluricentric Languages : A Typology // Non-Dominant Varieties of Pluricentric Languages. Getting the Picture. In Memory of Michael Clyne / ed. by R. Muhr. Frankfurt a/M : Lang, 2012. P. 23-48.

Mustajoki A. Challenges in the Standardisation of Contemporary Russian // Prescription and Tradition in Language: Establishing Standards across Time and Space / ed. by I. Tieken-Boon van Ostade, C. Percy. Bristol : Multilingual Matters, 2016. P. 288-302.

Mustajoki A., Protassova E. Russification of Western Concepts: Political Will and Crisis in a Russian Way // Understanding Russianness / ed. by R. Alapuro, A. Mustajoki, P. Pesonen. N. Y. : Routledge, 2012. P. 32-52.

Muth S. Russian Language Abroad: Viewing Language through the Lens of Commodification (Introduction to a Special Issue) // Russian J. of Linguistics. 2017. № 3. P. 463-675. DOI 10.22363/2312-9182-2017-21-3-463-492.

Post-Soviet Migration and Diasporas : From Global Perspectives to Everyday Practices / ed. by M. Nikolko, D. Carment. L. : Palgrave Macmillan, 2017. 179 p.

Ritzau U., Madsen L. M. Speaker Perspectives, Linguistic Hybridity, and Language Learning // Critical Perspectives on Linguistic Fixity and Fluidity : Languagised Lives / ed. by J. Jaspers, L. M. Madsen. N. Y. : Routledge, 2019. P. 192-213. 
Russian Language in the Multilingual World / ed. by A. Nikunlassi, E. Protassova. Helsinki : Univ. of Helsinki, 2019. 401 p.

The Russian Language Outside the Nation : Speakers and Identities / ed. by L. RyazanovaClarke. Edinburgh : Edinburgh Univ. Press, 2014. 304 p.

The Soft Power of the Russian Language : Pluricentricity, Politics and Policies / ed. by A. Mustajoki, E. Protassova, M. Yelenevskaya. L. : Routledge, 2020. 262 p.

Yelenevskaya M., Protassova E. Global Russian: Between Decline and Revitalization // Russian J. of Communication. 2015. № 2. P. 139-149. DOI 0.1080/19409419.2015.1044599.

\section{References}

Bakhtin, M. M. (2017). Slovo v romane [Word in the Novel]. Moscow, Pal'mira. 229 p.

Berdy, M. A. (2019). Is Your Language Sordid and Gross? In Moscow Times [website]. Nov. 15. URL: https://themoscowtimes.com/2019/11/15/is-your-language-sordid-andgross-a68197 (accessed: 04.06.2020)

Bezyaeva, M. G. (2017). Kommunikativnoe pole normy v zvuchashchem tekste [Communicative Field of the Norm in the Sounding Language]. In Russkii yazyk za rubezhom. No. 2, pp. 24-30.

Clyne, M. (1992). Pluricentric Languages. Different Norms in Different Countries. Berlin, Mouton de Gruyter. 481 p.

Comrie, B., Stone, G., Polinsky, M. (1996). The Russian Language in the Twentieth Century. Oxford, Clarendon Press. XI, 385 p.

Coupland, N., Kristiansen, T. (2011). SLICE: Critical Perspectives on Language (De) Standardisation. In Kristiansen, T., Coupland, N. (Eds.). Standard Languages and Language Standards in Changing Europe. Oslo, Novus, pp. 11-35.

Emel'yanenko, V. (2020). Esli ne russkii yazyk - kak nam rodnit'sya? [If Not the Russian Language, How Could We Be Related?]. In Rossiiskaya gazeta. No. 48. March 4. URL: https://rg.ru/2020/03/04/pochemu-v-konstitucii-neobhodima-popravka-o-russkomiazyke.html (accessed: 04.06.2020).

Goodman, K. S., Goodman, Y. M. (2014). Making Sense of Learners, Making Sense of Written Language. N. Y., Routledge. 288 p.

Guseinov, G. Ch. (2003). D. S. P. Sovetskie ideologemy v russkom diskurse 1990-kh [D. S. P. Soviet Ideologemes in the Russian Discourse]. Moscow, Tri kvadrata. 272 p.

Guseinov, G. Ch. (2012a). Novaya rol' russkogo yazyka v mire kak predmet izucheniya i prepodavaniya [The New Role of the Russian Language in the World as an Object of Learning and Teaching]. In Gefter [website]. May 10. URL: http://gefter.ru/archive/4359 (accessed: 04.06.2020).

Guseinov, G. Ch. (2012b). Nulevye na konchike yazyka: kratkii putevoditel' po russkomu diskursu [The 2000s on the Tip of the Tongue: A Short Guide on Russian Discourse]. Moscow, Izdatel'skii dom "Delo" Rossiiskoi akademii narodnogo khozyaistva i gosudarstvennoi sluzhby pri Prezidente Rossiiskoi Federatsii. 240 p.

Isurin, L. (2011). Russian Diaspora: Culture, Identity, and Language Change. Gottingen, Walter de Gruyter. 249 p.

Kamusella, T. (2018). Russian: A Monocentric or Pluricentric Language? In Colloquia Humanistica, No. 7, pp. 153-196. DOI 10.11649/ch.2018.010.

Karasik, V. I., Dmitrieva, O. A. (2005). Lingvo-kul'turnyi tipazh: k opredeleniyu ponyatiya [Linguo-Cultural Type: Toward the Definition of the Term]. In Karasik, V. I. (Ed.). Aksiologicheskaya lingvistika: lingvokul'turnye tipazhi. Volgograd, Paradigma, pp. 5-25.

Katona, É. (2019). Russian Pluricentricity in Development: Russian in Estonia as an Example. In Muhr, R., Mas Castells, J. A., Rueter, J. (Eds.). European Pluricentric Languages in Contact and Conflict. Berlin, Lang, pp. 11-25.

Kolesnikov, A. (2019). Zakonno russkie [Legally Russian]. In Kommersant". No. 203. URL: https://kommersant.ru/doc/4149158 (accessed: 04.06.2020).

Kolesov, V. V. (1998). Russkaya rech': vchera, segodnya, zavtra [Russian Speech: Yesterday, Today, Tomorrow]. St Petersburg, Yuna. 248 p. 
Krongauz, M. (2008). Russkii yazyk na grani nervnogo sryva [The Russian Language on the Verge of a Nervous Breakdown]. Moscow, Znak, Yazyki slavyanskikh kul'tur. $232 \mathrm{p}$.

Krysin, L. P. (2007). Russkaya literaturnaya norma i sovremennaya rechevaya praktika [Russian Literary Norm and the Contemporary Speech Practice]. In Russkii yazyk v nauchnom osveshchenii, No. 2, pp. 5-17.

Krysin, L. P. (2011). Variativnost' normy kak estestvennoe svoistvo literaturnogo yazyka [Variability of the Norms as a Natural Characteristic of the Literary Language]. In Izvestiya RAN. Seriya literatury i yazyka. Vol. 70. No. 4, pp. 3-8.

Krysin, L. P. (2012). Kul'tura rechi i funktsional'naya sotsiolingvistika [Culture of Speech and the Functional Sociolinguistics]. In Voprosy kul'tury rechi. Sbornik statei. Moscow, Institut russkogo yazyka imeni V. V. Vinogradova RAN, pp. 38-44.

Larina, T., Mustajoki, A., Protassova, E. (2017). Dimensions of Russian Culture and Mind. In Mustajoki, A., Lehtisaari, K. (Eds.). Philosophical and Cultural Interpretations of Russian Modernisation. N. Y., Routledge, pp. 7-19.

Maiorov, A. P. (Ed.). (2013). Regional'nye varianty natsional'nogo yazyka [Regional Varieties of the National Language]. Ulan-Ude, Izdatel'stvo Buryatskogo universiteta. 295 p.

Muhr, R. (2012). Linguistic Dominance and Non-Dominance in Pluricentric Languages: A Typology. In Muhr, R. (Ed.). Non-Dominant Varieties of Pluricentric Languages. Getting the Picture. In Memory of Michael Clyne. Frankfurt a/M, Lang, pp. 23-48.

Mustajoki, A. (2013). Raznovidnosti russkogo yazyka: analiz i klassifikatsiya [Varieties of the Russian Language: Analysis and Classification]. In Voprosy yazykoznaniya. No. 5, pp. 3-17.

Mustajoki, A. (2016). Challenges in the Standardisation of Contemporary Russian. In Tieken-Boon van Ostade, I., Percy. C. (Eds.). Prescription and Tradition in Language. Establishing Standards across Time and Space. Bristol, Multilingual Matters, pp. 288-302.

Mustajoki, A. (2019). Chto takoe "vladenie yazykom" i kakovy istoki sovremennoi metodiki prepodavaniya russkogo yazyka kak inostrannogo [What is "Language Proficiency" and What Are the Sources of the Modern Methods of Teaching Russian as a Foreign Language]. In Karasik, V. I. (Ed.). No my sokhranim tebya, russkii yazyk! Moscow, Flinta, pp. 353-361.

Mustajoki, A., Protassova, E. (2012). Russification of Western Concepts: Political Will and Crisis in a Russian Way. In Alapuro, R., Mustajoki, A., Pesonen, P. (Eds.). Understanding Russianness. N. Y., Routledge, pp. 32-52.

Mustajoki, A., Protassova, E., Yelenevskaya, M. (Eds.). (2020). The Soft Power of the Russian Language: Pluricentricity, Politics and Policies. L., Routledge. 262 p.

Muth, S. (2017). Russian Language Abroad: Viewing Language through the Lens of Commodification (Introduction to a Special Issue). In Russian J. of Linguistics. No. 3, pp. 463-675. DOI 10.22363/2312-9182-2017-21-3-463-492.

Natitnik, A. (2019). "Esli lyudi govoryat ne kak my, nam kazhetsya, chto oni plokhie" ["If people do not speak like us, it seems to us that they are bad"]. In Harvard Business Rev. - Rossiya [website]. December 24. URL: https://hbr-russia.ru/biznes-i-obshchestvo/ fenomeny/817433 (accessed: 04.06.2020).

Nikolko, M., Carment, D. (Eds.). (2017). Post-Soviet Migration and Diasporas: From Global Perspectives to Everyday Practices. L., Palgrave Macmillan. 179 p.

Nikunlassi, A., Protassova, E. (Eds.). (2019). Russian Language in the Multilingual World. Helsinki, Univ. of Helsinki. 401 p.

Noyanzina, O. E., Omel'chenko, V. A., Surtaeva, O. V. (2018). Prioritety gosudarstvennoi politiki Rossiiskoi Federatsii v oblasti sfer ispol'zovaniya russkogo yazyka [Priorities of the State Policy of the Russian Federation in the Sphere of the Russian Language]. In Society and Security Insights. Vol. 1. No. 4, pp. 125-140. DOI 10.14258/ssi(2018)4-09.

O Strategii gosudarstvennoi natsional'noi politiki Rossiiskoi Federatsii na period do 2025 goda. Ukaz Prezidenta RF ot 19 dekabrya. No. 1666. [About the Strategy of the State National Policy of the Russian Federation for the Period till the Year 2025. Decree of the President of the Russian Federation. December 19]. (2012). In Garant.Ru. Informatsionno-pravovoi portal. URL: https://www.garant.ru/products/ipo/prime/doc/70184810 (accessed: 04.06.2020) 
Ob utverzhdenii vedomstvennoi tselevoi programmy "Nauchno-metodicheskoe, metodicheskoe i kadrovoe obespechenie obucheniya russkomu yazyku i yazykam narodov Rossiiskoi Federatsii”. Rasporyazhenie Minprosveshcheniya Rossii ot 16.05.2019 No. R-60 [About the Endorsement of the Branch Targeted Programme "Scholarly, Methodical, and Personnel Provision of Teaching of the Russian Language and Languages of the Peoples of the Russian Federation". Order of the Ministry of Education of Russia as of May 16, 2019. No. R-60]. (2019). In Konsul'tantPlyus [website]. URL: http://www.consultant.ru/ document/cons_doc_LAW_356191 (accessed: 04.06.2020).

Pletneva, A. A. (2017). Narodnoe pravopisanie i reforma orfografii 1917-1918 godov [Popular Spelling and the Orthography Reform 2017-2018]. In Trudy Instituta russkogo yazyka imeni $V$. V. Vinogradova. Vol. 13, pp. 466-473.

Ritzau, U., Madsen, L. M. (2019). Speaker Perspectives, Linguistic Hybridity, and Language Learning. In Jaspers, J., Madsen, L. M. (Eds.). Critical Perspectives on Linguistic Fixity and Fluidity: Languagised Lives. N. Y., Routledge, pp. 192-213.

Rozhkova, E. (2019). Edinyi zhurnalistskii ekzamen [Unified Journalist Examination]. In Kommersant". November 23. URL: https://www.kommersant.ru/doc/4170171 (accessed: 04.06.2020).

Ryazanova-Clarke, L. (Ed.). (2014). The Russian Language Outside the Nation: Speakers and Identities. Edinburgh, Edinburgh Univ. Press. 304 p.

Savel'eva, L. V. (2000). Russkoe slovo: konets XX veka [Russian Word: The End of the $20^{\text {th }}$ Century]. St Petersburg, Logos. 213 p.

Severskaya, O. I. (2018). Orfograficheskie normy skvoz' prizmu paronimii i skhodnozvuchiya [Spelling Norms through the Prism of Paronymy and Similar-Sounding]. In Verbitskaya, L. A. (Ed.). Yazykovaya norma. Vidy i problem. St Petersburg, Rossiiskii gosudarstvennyi pedagogicheskii universitet imeni A. I. Gertsena, pp. 191-200.

Shaibakova, D. D., Maimakova, A. D., Meiramova, S. A. (Eds.). (2016). Plyuritsentricheskie yazyki [Pluricentric Languages]. Almaty, Ylaғat. 244 p.

Turkova, K. (2019). Kakie slova besyat russkikh i amerikantsev? [What Kind of Words Drive Russians and Americans Crazy?]. In Golos Ameriki. November 27. In Facebook [website]. URL: https://www.facebook.com/watch/?v=445762846124011 (accessed: 30.04.2021).

Yelenevskaya, M., Protassova, E. (2015). Global Russian: Between Decline and Revitalization. In Russian J. of Communication. No. 2, pp. 139-149. DOI 0.1080/19409419.2015.1044599.

Zagorovskaya, O. V. (2016). Normy russkogo literaturnogo yazyka: tipologiya i osnovaniya dlya klassifikatsii [The Norms of the Russian Literary Language: Typology and Grounds for Classification]. In Izvestiya Voronezhskogo gosudarstvennogo pedagogicheskogo universiteta. Seriya: Pedagogicheskie nauki. No. 3, pp. 121-126.

Zelenin, A. (2007). Yazyk russkoi emigrantskoi pressy (1919-1939) [The Language of the Emigrant Press (1919-1939)]. Tampere, Univ. of Tampere. 663 p. 